\title{
Agave pulquero (Agave salmiana), socio-economic and agro-ecological importance and its development perspectives: a literature review
}

\author{
Sandra Blas-Yañez ${ }^{1} \bullet \quad$ Humberto Thomé-Ortiz ${ }^{2 *}$
}

${ }^{1}$ Universidad Politécnica de Atlacomulco, Atlacomulco, Estado de México, México.

${ }^{2}$ Instituto de Ciencias Agropecuarias y Rurales. Universidad Autónoma del Estado de México, 50090, El Cerrillo Piedras Blancas, Toluca, Estado de México, México. E-mail: humbertothome@hotmail.com. "Corresponding author.

ABSTRACT: Historically, the agave pulquero (Agave spp.) has played an important ecological, economic, social, and cultural role in Mexico. Based on a systematic exploratory review of 125 scientific documents, four areas of knowledge associated with the study of agave pulquero were identified: i) biochemistry (46,4\%), ii) socioeconomics (20\%), iii) cultural studies (11,2\%), and iv) agroecology $(22,4 \%)$. Research converges on the need to value and preserve agaves since they can play an important role in rural development actions and the life quality of future societies, depending on the diversity of food, industrial, agro-ecological and cultural uses they provide. However, there is a fragmentary construction of the research problems that prevent a comprehensive vision of the producing territories as subjects of development. It is concluded that it is necessary to generate interdisciplinary perspectives for the valorization of the agave pulquero as an asset of rural development, based on inclusive innovation strategies, adapted to the specific needs of producers and consumers.

Key words: inclusive innovation, biotechnology, rural development, multidiscipline.

Agave pulquero (Agave salmiana), importância socioeconômica e agroecológica e suas perspectivas de desenvolvimento: uma revisão da literatura

RESUMO: Historicamente, o agave pulquero (Agave spp.) tem desempenhado um importante papel ecológico, econômico, social e cultural no México. Com base em uma revisão exploratória sistemática de 125 documentos científicos, quatro áreas de conhecimento associadas ao estudo do agave pulquero foram identificadas: i) bioquímica (46,4\%), ii) socioeconomia (20\%), iii) estudos culturais (11, 2\%) e iv) agroecologia (22,4\%). A pesquisa converge para a necessidade de valorizar e preservar as agaves, uma vez que podem desempenhar um papel importante nas ações de desenvolvimento rural e na qualidade de vida das sociedades futuras, dependendo da diversidade de usos alimentícios, industriais, agroecológicos e culturais que proporcionam. No entanto, há uma construção fragmentária dos problemas de pesquisa que impedem uma visão abrangente dos territórios produtores como sujeitos de desenvolvimento Conclui-se que é necessário gerar perspectivas interdisciplinares para a valorização do agave pulquero como um ativo de desenvolvimento rural, baseado em estratégias de inovação inclusivas, adaptadas às necessidades especificas de produtores e consumidores.

Palavras-chave: inovação inclusiva, biotecnologia, desenvolvimento rural, multidisciplina.

\section{INTRODUCTION}

The traditional conception of rural development, until recently, focused on the productive reconversion of the territory aiming the production of commodity crops with high profitability in global markets (BERNSTEIN, 2010; PATEL, 2013). However, some more recent development perspectives have set their sights on the potential represented by native and endemic products, given their cultural and functional characteristics, which respond to specific needs of contemporary society (AQUILANTI et al., 2020; GUERRERO et al. al., 2019).

Global food production faces challenges such as desertification, increased demand for healthy food, and competition for agricultural land (NICOLIA et al., 2014). The response to global crises requires low impact agrifood systems, hydraulic efficiency, crops resistant to climate change, independent of non-renewable resources, capable of generating energy inputs, but that do not compete for fertile soil for food production. 
The maguey pulquero (Agave spp.), represented a resource of high economic, cultural, and nutritional importance in Mexico since preHispanic times (HERNÁNDEZ, 1979). The main product derived from this plant is pulque, an alcoholic beverage with a whitish, viscous, slightly acidic, and low alcohol content (4-7 $\left.{ }^{\circ} \mathrm{GL}\right)$, resulting from the fermentation of the fresh sap (commonly called aguamiel) that is extracted from the base of the plant stem (ESCALANTE et al., 2016).

During the colonial era, it became an important agro-industry for the country's economy (LEAL \& ROUNTREE, 2011). However, in the mid19th century, the pulque agribusiness stagnated due to several factors, such as the introduction of the brewing industry, agrarian reform, anti-alcohol campaigns and drives to discredit pulque (RAMÍREZ, 2015; VALADEZ, 2014), due to the devaluation of the product and the loss of cultivated areas (AGUILAR et al., 2014). Recently, in the context of the revalorization of the biological and cultural heritage, development opportunities have been opened for the agave production chain.

Facing the global trend of consuming products of natural origin, it is considered appropriate to carry out a multidisciplinary analysis of scientific production on agave pulquero, to understand the changes that this natural resource faces.

Among the manuscripts reviewed is the special issue of Fermented foods in health and disease prevention (FRIAS et al., 2016); The Science of Beverages edited by GRUMEZESCU \& HOLBAN, (2019), and the book Beyond pulque and tepache: the indigenous non-distilled alcoholic beverages of Mexico (GODOY et al., 2003). This international research provides innovative knowledge on fermented beverages and aim to consolidate high value-added agribusinesses based on functional and nutraceutical foods (FRIAS et al., 2016).

Although, scientific research seeks to contribute to each disciplinary field in addition to generating and promoting knowledge (CONTRERAS et al., 2015), most of them tend aim highly specialized audiences such as the agri-food industry or the scientific community. For this reason, it is necessary to increase its incidence in the producing communities, to support the weakest economic sectors, increase the capacity for innovation at the local level, make social use of knowledge and give greater legitimacy to scientific research (AROCENA \& SUTZ, 2009; DEVAUX et al., 2018).

Therefore, it is necessary to promote the alliance between research and innovation with inclusive processes capable of influencing social, economic, and technological development for the Mexican agricultural sector (HEEKS et al., 2014; AMARO \& GORTARI, 2016).

In this sense, the question guiding this literature review is: What is the contribution of scientific research on agave pulquero, developed in the last 20 years, in terms of its possible impacts on rural development? To try to answer the question, various research approaches are assembled, from the social and economic sciences due to their sociocultural importance, to the agroecological and biochemical sciences that perceive their agroindustrial and economic potential.

The objective of this literature review is to reflect on the importance of scientific contributions about the study of the pulquero agave and its possible horizons of rural development in the producing territories.

\section{METHODOLOGY}

To identify the areas of knowledge that have contributed to the study of the relationship between agave pulquero and rural development, a systematic exploratory review was carried out (LEVAC et al., 2010) of the literature available in the Elsevier, Scopus, Springer, WorldWideScience, and PubMed databases were performed between January 2019 and February 2020. An exploratory approach was chosen since a systematized body of knowledge on the problem studied was not identified. Furthermore, this first approach is the basis for the identification of knowledge gaps and the generation of new lines of research.

Those search engines that had a multilanguage real-time search platform were chosen, with various filters and ordering options for the results, thereby facilitating systematic access to publications from different fields of knowledge. Therefore, they are considered as sources of updated, stable, and reliable information to retrieve the relevant scientific records (ELLIS et al., 2018).

Only original research papers were selected. The search was carried out based on a semantic criterion, using the keywords: pulque, aguamiel, and Agave salmiana, this selection is based on the need to include those words that strictly refer to the most popular variety of agave pulquero (MORALÓPEZ et al., 2011; ÁLVAREZ-RÍOS et al., 2020c) and its derivatives.

The foregoing allows restricting the search for this variety since in Mexico there is a vast scientific production of other varieties of agave, particularly those intended for the production of distillates. 
To generate a global panorama of the research on maguey pulquero (Agave salmiana), documents produced during the last 20 years were considered. While to understand the evolution of the studies, papers, and books written between 1950 and 1998 were reviewed. The information was organized using data tables, based on thematic axes. A total of 125 records were collected, compiled in pdf version (Table 1). They were classified according to the disciplinary fields in which they were developed. The data was ordered in a database in Excel version 2010.

Finally, a thematic analysis of the results was carried out (Table 2) (ARKSEY and O'MALLEY, 2005). It was reflected on the usefulness of scientific contributions to activate rural development dynamics, with innovations of high scientific and technological content capable of invigorating the agave pulquero production system, generating economically profitable productive innovations, improving the life quality of producers.

\section{General aspects and uses of agaves} The maguey pulquero in Mexico

The maguey (common name for individuals of the Agave genus), originated about 12 million years ago in the arid regions of the current territory of northern Mexico and the southern United States of America (MONJA-MIO et al., 2019). They are perennial plants that maintain a crassulacean acid metabolism (CAM), a low demand for nutrients, and efficient use of water (GUZMÁN \& CONTRERAS, 2018), they can survive in extreme conditions, including high altitude mountain places, they have a single event reproductive in their life, and contain a high concentration of fructans as reserve substances (CASTILLO et al., 2019).

In Mexico, the maguey has been used since pre-Hispanic times by its native peoples (GENTRY,
1982) to satisfy food, clothing, and construction needs (MACNEISH, 1964). Currently, 22 use categories have been reported for 107 agave taxa present in Mexico (COLUNGA-GARCÍA et al. 2007).

The maguey pulquero is considered an emblematic plant of the Mexican Central Highlands, which is used to obtain sap and produce pulque, a fermented drink associated with the food culture of various ethnic groups, valued in urban and rural contexts (ÁLVAREZ-RÍOS et al., 2020ab). Currently, there are more than 8 thousand hectares planted with maguey pulquero, distributed in the states of Guanajuato, Guerrero, Hidalgo, Michoacán, Puebla, Querétaro, San Luis Potosí, Tlaxcala, State of Mexico and Veracruz (Servicio de Información Agroalimentaria y Pesquera SIAP, 2018).

Among the different varieties of maguey that are most used to produce aguamiel and pulque are: Agave macroculmis, A. mapisaga, A. mapisaga var. lisa, A. salmiana, A. angustifolia, A. ferox, A. salmiana subsp. crassispina and $A$. tecta (COLUNGA-GARCÍA et al., 2007). Of which, the Agave salmiana var. Salmiana is the most suitable for pulque production due to its high acceptance among consumers (MORA-LÓPEZ et al., 2011; ÁLVAREZ-RÍOS et al., 2020c), for this reason, this review will focus exclusively on the research generated on this variety.

The maguey pulquero differs from other agaves used for the elaboration of alcoholic beverages, due to its fermentation characteristics that require low technification in its production processes, so that few changes have been experienced since the pre-Hispanic era (ESCALANTE et al., 2016; ROBERTSON \& CABRERA-CORTÉS, 2017). In addition to social, political, and economic factors that, historically, have relegated it to the economic and social marginalization in which it is commercialized (BLAS-YAÑEZ et al.,

Table 1 - Classification of 125 scientific documents on maguey pulquero published between 2000 and 2020.

\begin{tabular}{lcc}
\hline Knowledge area & Number of Publications & $\%^{*}$ \\
\hline Biochemistry & 58 & 46.4 \\
Agroecology & 28 & 22.4 \\
Socioeconomics & 25 & 20.0 \\
Cultural studies & 14 & 11.2 \\
Total & 125 & 100 \\
\hline
\end{tabular}

*Percentage of total documents reviewed.

Source: own elaboration (2020). 
Table 2 - Trends and research challenges on the maguey pulquero.

\begin{tabular}{|c|c|c|c|}
\hline Discipline & Research topic & Trends & Challenges \\
\hline \multirow{3}{*}{ Biochemistry } & $\begin{array}{l}\text { Chemical and } \\
\text { microbiological studies }\end{array}$ & Functional foods development & $\begin{array}{l}\text { Multidisciplinarity } \\
\text { Consumer niches } \\
\text { Rural Agroindustry }\end{array}$ \\
\hline & Biotechnology & Genetic improvement and micropropagation & $\begin{array}{l}\text { Local germplasm banks } \\
\text { Local management of biotechnology }\end{array}$ \\
\hline & $\begin{array}{l}\text { Development of industrial } \\
\text { inputs }\end{array}$ & $\begin{array}{l}\text { Development of biofuels, biological } \\
\text { pesticides and biomaterials }\end{array}$ & $\begin{array}{l}\text { Inclusive innovation and local } \\
\text { technology for development }\end{array}$ \\
\hline \multirow[b]{2}{*}{ Agroecology } & Ecological functions & Soil remediation and soil recovery & \multirow{2}{*}{$\begin{array}{l}\text { Public policies for the preservation and } \\
\text { sustainable use of the agave pulquero }\end{array}$} \\
\hline & $\begin{array}{c}\text { Ecogeographical } \\
\text { distribution of species }\end{array}$ & Variability and taxonomy & \\
\hline \multirow[t]{2}{*}{ Socioeconomics } & Legal regulations & $\begin{array}{l}\text { Laws for the promotion, conservation, and } \\
\text { protection }\end{array}$ & $\begin{array}{l}\text { Application of the legal framework } \\
\text { Development of programs for the } \\
\text { preservation and sustainable use of } \\
\text { agave }\end{array}$ \\
\hline & Competitiveness & $\begin{array}{l}\text { Uses and applications of agave and its } \\
\text { derivatives (industrial, food and recreational) }\end{array}$ & $\begin{array}{c}\text { Productive diversification and } \\
\text { innovation }\end{array}$ \\
\hline Cultural studies & $\begin{array}{l}\text { Sociocultural importance } \\
\text { of agave production and } \\
\text { consumption }\end{array}$ & Studies on cultural identities & $\begin{array}{l}\text { Strategies for the sociocultural } \\
\text { reproduction of the agave crop }\end{array}$ \\
\hline
\end{tabular}

Source: own elaboration (2020).

2018; 2019). This has caused that there are no precise statistical data on the production of maguey pulquero, aguamiel, and pulque (AGUILAR et al., 2014).

The scientific community has indicated that agave has a high agro-ecological value, given its ability to retain soil, infiltrate moisture (TORRES-GARCÍA et al., 2019), and it's potential to phytostabilize and remediate contaminated soils (PERALES et al., 2020). Also, the decrease in the cultivated area of maguey and the erosion of knowledge about its use (AGUILAR et al., 2014; ÁLVAREZ-DUARTE et al., 2018) lead to the loss of its genetic variability, which puts it in danger of extinction to various endemic species (MONJA-MIO et al., 2019) ecologically, economically and culturally relevant in rural areas of Mexico.

Given these concerns, in recent years various policies have been generated for the cultural revaluation of maguey and pulque as iconic elements of national gastronomy, this has been reflected with the rise of fairs, museums, tourist routes, urban pulque shops who seek to rescue the crop and claim its identity value (TORRES-NIETO, 2013; ROJASRIVAS et al., 2019).

Besides, biotechnological research has been generated on industrial (HOLTUM et al., 2011;
NAVA-CRUZ et al., 2015), agrifood (SANTOS-ZEA et al., 2016; ÁLVAREZ-RÍOS et al., 2020a), and the genetic potential of agave (MONJA-MIO et al., 2019; ÁLVAREZ-RÍOS et al., 2020b); however, the transfer of technology and applied science to enhance rural development has been minimal (ESCALANTE et al., 2016). Therefore, the pulque agribusiness is maintained with low technification, in a condition of informality, coupled with the poor application of public policies on the production, use, and marketing of pulque and other maguey products (BLASYAÑEZ et al., 2018 ).

\section{Socioeconomic studies on the maguey pulquero}

The first governmental interventions on the maguey pulquero were fiscal, sanitary and public order policies during the 19th century (VALADEZ, 2014; RAMÍREZ, 2015), in the first half of the 20th century, the agrarian reform, led to the dismantling of the pulque haciendas, the productive reconversion to annual crops such as barley and abandonment of replanting agave (GONÇALVES DE LIMA, 1956; RAMÍREZ, 2015) that led to the crisis of the pulque industry.

The disappearance of the maguey plantations and their negative effects on ecology 
and economy was the starting point to address the problem of maguey in Mexico, from the perspective of agroecology and rural sociology, for the sake of thinking about comprehensive management of the crop.

The states of the central valley of the country have promoted various state laws for the promotion, conservation, and protection of the maguey. However, there are still no evaluations on the practical utility of such initiatives, to remedy the problems of the producers, such as the reduction of cultivated areas, the theft of plants and leaves, low technification, and limited commercial competitiveness.

Currently, the pulque that is marketed locally and regionally is maintained in small-scale production systems, generally developed for selfconsumption and informal trade (ÁLVAREZ-RÍOS, 2020ab, BLAS-YAÑEZ et al, 2018).

From the social and economic perspective, the maguey pulquero is considered as an endogenous resource with the potential to promote rural development (NARVÁEZ-SUÁREZ et al., 2016), based on valorization strategies such as tourism (TORRES-NIETO, 2013) and the production and marketing of edible insects that grow and feed on this plant (ESPARZA-FRAUSTO et al., 2008; LLANDERAL-CÁZARES et al., 2010).

Producer typologies have been proposed, according to their production capacity and forms of commercialization (BLAS-YAÑEZ et al., 2019), as well as consumer studies to analyze the market niche represented by young consumers (ROJASRIVAS et al., 2019). From the anthropology of food, the consumption spaces of pulque and the social relationships that develop in them are analyzed (TONER, 2011; BLAS-YAÑEZ et al., 2018).

\section{Cultural studies on the maguey pulquero}

Some studies have analyzed the historical transformations of economic activities linked to the maguey pulquero (RAMÍREZ, 2015; VALADEZ, 2014; WRIGHT, 2009) and on the importance of agave for the establishment and survival of Mesoamerican civilizations (PARSONS \& DARLING, 2000).

Other research focuses on the value of the maguey pulquero for pre-Columbian societies, considering its social and ceremonial importance (GONÇALVES DE LIMA, 1956; FOURNIER \& BARRIOS, 2012; MAZZETTO \& MORAGAS, 2015), as well as the evolution of the tools used for the extraction and fermentation of sap (ÁLVAREZPALMA et al., 2016; ROBERTSON \& CABRERACORTÉS, 2017). The social systems that support the pulque production chain and its consumers
(NEMSER, 2011) and the symbolic representations of the maguey in the construction of national identity have also been analyzed (WRIGHT, 2009).

\section{Contributions of agroecology to the study of the maguey pulquero}

Agroecological studies focus on three main aspects: i) variability, taxonomy, and eco-geographical distribution of species (AGUILAR et al., 2014; TORRES et al., 2016), which describe the agaves used for pulque and mead production (ROJAS et al., 2007; COLUNGA-GARCÍA et al. 2007; REYES-AGÜERO et al., 2019); ii) ecological functions (MORENOCALLES et al, 2013; TORRES-GARCÍA et al., 2019), with emphasis on genetic erosion and reduction of cultivated areas (FLORES-BENÍTEZ et al., 2007; ROJAS et al., 2007; REYES-AGÜERO et al., 2019) and iii) genetic improvement to improve productivity and conserve threatened wild species. The research by MONJA-MIO et al., (2019) and NAVA-CRUZ et al., (2015), highlights the importance of in situ, in vivo, and in vitro techniques for the conservation of germplasm. Biotechnological development is essential to optimize the production, diversification, and technology transfer of agave pulquero in the future (PUENTE-GARZA et al., 2015).

\section{Chemical and microbiological studies of agave}

Since the first decades of the 20th century, chemical and microbiological studies have been carried out on aguamiel and pulque (LOYOLA-MONTEMAYOR, 1956; SÁNCHEZMARROQUÍN, 1967). The first research (ANDERSON, 1946; SÁNCHEZ-MARROQUÍN and HOPE, 1953), emerged in an ideological and political context: hygienist, moralist, colonizer, and modernist (VARGAS, 2019).

The second wave of researches emerged in a context of hypermodernity (BECK, 2006), where the microbiological and nutraceutical potential of maguey pulquero and its derivatives is taken up, for use in biotechnological applications and bioprocesses (LAPPE-OLIVERAS et al., 2008; NAVA-CRUZ et al., 2015).

The biotechnological applications of maguey pulquero are divided into three strands: i) food biotechnology, based on the analysis of microbial behavior (VALADEZ-BLANCO et al., 2012; GUTIÉRREZ-URIBE et al., 2017) prebiotic content (CASTILLO et al., 2019; CASTRO-ZAVALA et al., 2015), probiotic content (LEAL-DÍAZ et al., 2015; CASTRO-ZAVALA et al., 2015; VILLARREALMORALES et al., 2019) and nutritional value 
(ESCALANTE et al., 2004; 2016; TOVAR-ROBLES et al., 2011) to infer its usefulness in gastrointestinal disorders (VILLAREAL-MORALES et al., 2019; MIRAMONTES-CORONA et al., 2019), and develop functional foods (RIVERA et al., 2010; FRÍAS et al., 2016; GILES-GÓMEZ et al., 2016); ii) agricultural biotechnology for genetic improvement (MONJAMIO et al., 2019), in vitro micropropagation (SILOSESPINO et al., 2007) and obtaining active components of industrial interest (PUENTE-GARZA et al., 2015 ). iii) Energy biotechnology to obtain cellulose (NAVA-CRUZ et al., 2015), bioethanol (DAVIS et al., 2011; HOLTUM et al., 2011; LÁINEZ et al., 2019), biogas, and hydrogen (RIVERA- VARGAS et al., 2016), light biomaterials (NARVÁEZ-ZAPATA \& SÁNCHEZ-TEYER, 2009) and as an adherent of composite polymers (HAQUE et al., 2016).

Agave salmiana can also contribute to remediating contaminated soils (PERALES et al., 2020) and the aguamiel can be used as a substrate in the production of nematodes for biocontrol of pests (ISLAS-LÓPEZ et al., 2005).

\section{DISCUSSION}

Scientific publications on public health and microbiology on pulque in the 19th century served to demonstrate, criticize and address sociocultural problems such as the non-responsible consumption of this drink, having repercussions in the conformation of regulatory frameworks that include public space, obligations tax, food safety, and production limits for agave pulquero.

This period of strong political and administrative restrictions also gave rise to new knowledge about the microbiological nature of pulque (LOYOLA-MONTEMAYOR, 1956; SÁNCHEZ-MARROQUÍN, 1967), providing new elements for its industrialization and conservation. However, these studies have generated incipient results due to their limited capacity to adapt to the socially constructed taste around this product, which is preferably consumed fresh and based on a social bond and trust with the producer. Pulque still faces adverse scenarios due to the implementation of global consumption patterns, which have spread the presence of cosmopolitan products such as wine and beer (LUTZ, 2012; RODRIGUES \& PARR,2019).

Nowadays, the findings from agroecology have drawn attention to the scarcity of plantations and the loss of endemic varieties of agave, where genetics and in vitro cultures raise efficiency in their application for the massive regeneration and preservation of said varieties. However, the appropriation processes on these technologies are still limited and have been little studied from the economic, social, and technological perspectives to delineate the local development scenarios that exist, based on endogenous resources such as the agave pulquero.

Despite the fact that Mexico is a territory with a great diversity of agaves and its cultivation is rooted in culture, it has not gone beyond local consumption, nor traditional forms of consumption (BLAS-YAÑEZ et al., 2018). However, the trends in scientific research are oriented towards technological development linked to functional foods and biomaterials (GILES-GÓMEZ et al., 2016; LÁINEZ et al., 2019). This means that a comprehensive rural development strategy should be based on the socialization of technology and the integration of farmers within the value chains and business vision of new products.

The foregoing denotes the lack of specific studies to be able to base an opinion on the viability for the industrialization of derivatives of the agave pulquero applied in specific local contexts, to generate information that allows designing interventions to improve the productivity and sustainability of the crop, oriented to increase its benefits for the rural sector.

With the systematization of the evidence, it is possible to indicate that access to knowledge is limited since it only passes through scientific journals or specialized databases. Hence, the need to promote strategies to disseminate knowledge and transfer technological applications to producers who experience conditions of marginalization and poverty, but are the ones who have ultimately preserved the resources and their associated knowledge.

In this vein, it is necessary to study the socio-cultural and structural conditions that hinder the effective appropriation of knowledge, to understand the rupture between scientific production and its empirical application in specific productive contexts, this division being a limiting aspect to achieve the inclusive innovation (HEEKS et al., 2014; DEVAUX et al., 2018) so necessary for rural societies in peripheral countries.

Therefore, our review calls for dialogue between different areas and disciplines of knowledge to obtain a comprehensive view of the problem studied. One of the lessons that we have learned regarding how the lines of research on the agave pulquero have been constructed is the marked division between the biotechnological, socio-cultural, and economicadministrative aspects. This division must be overcome 
to generate inclusive, culturally appropriate, and feasible innovation processes in the market.

In summary, the state of knowledge about the pulquero agave indicates the need to move from a basic research stage to an applied research stage, with a strong component of territorial innovation and rural extensionism.

\section{CONCLUSION}

The reviewed scientific publications illustrate the growing interest of the sciences in the study of the maguey pulquero, given its biological characteristics and its great capacity for edaphoclimatic adaptation, it opens up various possibilities for development and innovation for local agave pulquero production systems, which face conditions of economic and environmental crisis.

The adoption of this potential implies the opening of new markets and the possibility of improving the quality of life of producers and consumers. However, it is necessary to have elements to determine its economic and social feasibility, as well as to overcome preconceptions regarding technological innovation as a restricted field for large companies, whose access is denied to rural producers.

However, there is a profound disarticulation between the academy, the industry, the State, and the social actors immersed in the preservation, production, and use of this plant. Therefore, the need to prosecute multidisciplinary projects that articulate economic, biotechnological, agri-food, and social aspects, to promote the full use of the maguey pulquero, as a resource that can influence the quality of life of future societies.

This literature review is expected to be useful in delineating research agendas in this area, based on a broad overview of the production, benefits, and conservation of this endogenous resource in rural communities.

Future research should propose empirical studies where the flow of scientific knowledge to rural communities is analyzed and the technology transfer for the production and transformation of the pulquero agave is evaluated.

\section{ACKNOWLEDGMENTS}

We would like to thank the Polytechnic University of Atlacomulco and the Institute of Agricultural and Rural Sciences of the Autonomous University of the State of Mexico for the financial and institutional supports for the development of this paper.

\section{DECLARATION OF CONFLICT OF INTERESTS}

The authors declare that there is no conflict of interest. The funding entities had no influence on the study design; nor in the collection, analysis or interpretation of the data; in the writing of the manuscript, nor in the decision to publish the results.

\section{AUTHORS' CONTRIBUTIONS}

The authors contributed equally to the manuscript.

\section{REFERENCES}

AGUILAR, B. et al. El estado actual de Agave salmiana y A. mapisaga del Valle de México. Revista Mexicana de Agroecosistemas, v.1, n.2, p.106-120. 2014. Available from: $<$ http://www.voaxaca.tecnm.mx/revista/docs/RMAE\%20vol\%20 12 2014/RMAE-2014 11\%20Agave Resumen.pdf>. Accessed: Jun. 23, 2019

ÁlVAREZ-DUARTE, M. C. et al. Conocimiento tradicional, cultivo y aprovechamiento del maguey pulquero en los municipios de Puebla y Tlaxcala. Polibotánica, n.45, p.205-222. 2018. Available from: <https://www.polibotanica.mx/ojs/index.php/ polibotanica/article/view/279>. Accessed: Jun. 23, 2019.

ÁLVAREZ-PALMA, A. et al. La explotación del maguey pulquero en la zona de Metztitlan: datos etnográficos y arqueológicos. Dimensión Antropológica, n.13, p.7-30. 2016. Available from: $<$ https://www.dimensionantropologica.inah.gob.mx/?p=1348>. Accessed: Jun. 23, 2019.

ÁLVAREZ-RÍOS, D. et al. Physical, Chemical, and Microbiological Characteristics of Pulque: Management of a Fermented Beverage in Michoacán, Mexico. Foods, v.9, n.3, p.361. 2020a. Available from: $<$ https://doi.org/10.3390/foods9030361>. Accessed: Jun. 23, 2019.

ÁLVAREZ-RÍOS, G. D. et al. Management, morphological and genetic diversity of domesticated agaves in Michoacán, México. Journal of Ethnobiology and Ethnomedicine, v.16, n.1, p.3. 2020b. Available from: <https://doi.org/10.1186/s13002-0200353-9>. Accessed: Jun. 23, 2019.

ÁlVAREZ-RÍOS, G. D. et al. Sistemas de manejo de maguey pulquero en México. Etnobiología, v.18, n.2, p.3-23. 2020 c. ISSN 1665-2703

AMARO, M.; GORTARI, R. Inclusive innovation in the Mexican agricultural sector: coffee producers in Veracruz. Economía Informa, v.400, p.86-104. 2016. Available from: <https://doi. org/10.1016/j.ecin.2016.09.006>. Accessed: Jun. 23, 2019.

ANDERSON, R. et al. A study of the nutritional status and food habits of Otomí Indians in the Mezquital Valley of Mexico. American Journal of Public Health, n.36, p.883-903. 1946. Available from: <https://www.ncbi.nlm.nih.gov/pmc/ articles/PMC1625980/>. Accessed: Jun. 23, 2019.

AQUILANTI, Lucia, et al. Valorization of Foods: From Tradition to Innovation. In The First Outstanding 50 Years of "Università Politecnica delle Marche". Springer, Cham, 2020. p.565-581. Available from: $<$ https://doi.org/10.1007/978-3-030-33832-9 36>. Accessed: Jun. 23, 2019. 
ARKSEY, H. et al. Scoping studies: towards a methodological framework. Int J Soc Res Methodol. v.8, n.1. 2005. p.19-32. Available from: <https://doi.org/10.1080/1364557032000119616> Accessed: Jun. 23, 2019

AROCENA, R.; SUTZ, J. Sistemas de innovación e inclusión social. Pensamiento Iberoamericano, v.5, n.2, p.99-120. 2009.

BECK, U. La sociedad del riesgo. Hacia una nueva modernidad. Barcelona: Paidós, 2006.

BLAS YAÑEZ, S. et al. Informal sale of pulque as a socia reproduction strategy. Evidence from central Mexico. Revista de Geografía Agrícola, n.62, p.49-67. 2019. Available from: <http:// dx.doi.org/10.5154/r.rga.2019.62.03>. Accessed: Jun. 23, 2019

BLAS-YAÑEZ, S. et al. Street sale of pulque and socio-spatial practices: A gender perspective in central Mexico. Journal of Ethnic Foods, n.5, p.4, p.311-316. 2018. Available from: <https:// www.sciencedirect.com/science/article/pii/S2352618118301719>. Accessed: Jun. 23, 2019. doi: 10.1016/j.jef.2018.10.005.

BERNSTEIN, H. Introduction: some questions concerning the productive forces. Journal of Agrarian Change, v.10, n.3, p.300-314. 2010. Available from: < https://doi.org/10.1111 /j.1471-0366.2010.00272.x>. Accessed: Jun. 23, 2019.

CASTILlo, A. et al. Agave salmiana fructans as gut health promoters: Prebiotic activity and inflammatory response in Wistar healthy rats. International journal of biological macromolecules, n.136, p.785-795. 2019. Available from: $<$ https://doi.org/10.1016/j. ijbiomac.2019.06.045>. Accessed: Jun. 23, 2019.

CASTRO-ZAVALA, A. et al. Prebiotic effects of Agave salmiana fructans in Lactobacillus acidophilus and Bifidobacterium lactic cultures. Natural product communications, v.10, n.11, p.19851988. 2015. Available from: <https://www.ncbi.nlm.nih.gov/ pubmed/26749843>. Accessed: Jun. 23, 2019

COLUNGA-GARCÍA, P. et al. Tradiciones en el aprovechamiento de los agaves mexicanos: una aportación a la protección legal y conservación de su diversidad biológica y cultural. En lo ancestral hay futuro: del tequila, los mezcales y otros agaves, p.229-248. 2007.

CONTRERAS, F. et al. The importance of academic publications: Some problems and recommendations to keep in mind. Idesia (Arica), v.33, n.4, p.111-119. 2015.

DAVIS, S. C. et al. The global potential for agave as a biofuel feedstock. GCB Bioenergy, n.3, p.68-78. 2011. Available from: $<$ https://doi.org/10.1111/j.1757-1707.2010.01077.x>. Accessed: Jun. 23, 2019.

DEVAUX, A. et al. Agricultural innovation and inclusive valuechain development: a review, Journal of Agribusiness in Developing and Emerging Economies, v.8, n.1, p.99-123. 2018. Available from: <https://doi.org/10.1108/JADEE-06-2017-0065>. Accessed: Jun. 23, 2019.

ELLIS, A. et al. What is food tourism?. Tourism Management n.68, p.250-263. 2018. Available from: $<$ https://doi.org/10.1016/j. tourman.2018.03.025>. Accessed: Jun. 23, 2019.

ESCALANTE, A. et al. Characterization of bacterial diversity in pulque, a traditional Mexican alcoholic fermented beverage, as determined by $16 \mathrm{~S}$ rDNA analysis. FEMS Microbiology
Letters, v.235, n.2, p.273-279. 2004. Available from: <https://doi. org/10.1111/j.1574-6968.2004.tb09599.x>. Accessed: Jun. 23, 2019.

ESCALANTE, A. et al. Pulque, una bebida fermentada alcohólica tradicional mexicana: aspectos históricos, microbiológicos y técnicos. Frontiers in microbiology, n.7, p.1026. 2016.

ESPARZA-FRAUSTO, G. et al. Insectos comestibles asociados a las magueyeras en el ejido Tolosa, Pinos, Zacatecas, México. Agrociencia, v.42, n.2, p.243-252. 2008. Available from: <http:// www.scielo.org.mx/pdf/agro/v42n2/v42n2a12.pdf $>$. Accessed: Jun. 23, 2019

FLORES-BENÍTEZ, S. et al. Genetic transformation of Agave salmiana by Agrobacterium tumefaciens and particle bombardment. Plant Cell Tiss Organ Cult, n.91, p.215-24. 2007. Available from: <https://doi.org/10.1007/s11240-007-9287-3>. Accessed: Jun. 23, 2019.

FOURNIER, P.; BARRIOS, L. M. Las bebidas mexicanas, pulque, mezcal y tesgüino. Arqueología mexicana, v.19, n.114, p.52-59. 2012.

FRÍAS, J. et al. (Eds.). Fermented foods in health and disease prevention. Academic Press: Elsevier. 2016.

GENTRY, H. S. On the evolution of agaves. Saguaroland Bull, v.36, n.3, p.27 -30. 1982.

GUERRERO, L. et al. Flipping the Tortilla: Social-ecological innovations and traditional ecological knowledge for more sustainable agri-food systems in Spain. Sustainability, vol.11, n.5, p.1222. 2019. Available from: <https://doi.org/10.3390/ su11051222>. Accessed: Jun. 23, 2019

GILES-GÓMEZ, M. et al. In vitro and in vivo probiotic assessment of Leuconostoc mesenteroides $\mathrm{P} 45$ isolated from pulque, a Mexican traditional alcoholic beverage. SpringerPlus, v.5, n.1, p.708. 2016. Available from: $<$ https://core.ac.uk/display/81094159>. Accessed: Jun. 23, 2019.

GODOY, A. et al. Más allá del pulque y el tepache: las bebidas alcohólicas no destiladas indígenas de México. México:UNAM, 2003.

GONCALVES DE LIMA, O. El maguey y el pulque en los códices mexicanos. México: Fondo de Cultura Económica, 1956. $279 \mathrm{p}$.

GRUMEZESCU, A.; HOLBAN, A. M. (Eds.). Alcoholic Beverages: Volume 7: The Science of Beverages. Woodhead Publishing, 2019.

GUTIÉRREZ-URIBE, J. A. et al. Pulque. In: Fermented Foods in Health and Disease Prevention. Academic Press, 2017. p. 543-556.

GUZMÁN, R.; CONTRERAS, J.C. Aguamiel and its fermentation: Science beyond tradition. Mexican Journal of Biotechnology, v.3, n.1, p.1-22. 2018. Available from: <https://doi.org/10.29267/ mxjb.2018.3.1.1>. Accessed: Jun. 23, 2019.

HAQUE, M. et al. Thermal and tensile mechanical behavior of polystyrene graft acetic anhydride-treated pulque fibers. Journal of natural fibers, v.13, n.2, p.125-136. 2016. Available from: $<$ https://doi.org/10.1080/15440478.2014.984057>. Accessed: Jun. 23, 2019.

Ciência Rural, v.51, n.4, 2021. 
HEEKS, R. et al. New models of inclusive innovation for development. Innovation and Development, v.4, n.2, p.175-185. 2014. Available from: <https://www.tandfonline.com/doi/abs/1 0.1080/2157930X.2014.928982>. Accessed: Jun. 23, 2019. doi: 10.1080/2157930x.2014.928982.

HERNÁNDEZ, J. J. La renta del pulque en Nueva España, 1663-1810. Sevilla: Escuela de Estudios Hispano-Americanos. C.S.I.C, 1979

HOLTUM, J. A. et al. Agave as a biofuel feedstock in Australia. Gcb Bioenergy, v.3, n.1, p.58-67. 2011. Available from: $<$ https://doi.org/10 $.1111 / \mathrm{j} .1757-1707.2010 .01083 . \mathrm{x}>$. Accessed: Jun. 23, 2019.

ISLAS-LÓPEZ, M. A. et al. Monoxenic production of the entomopathogenic nematode Steinernema carpocapsae using culture media containing agave juice (aguamiel) from Mexican maguey-pulquero (Agave spp). Effects of the contents of nitrogen, carbohydrates, and fat on infective juvenile production. Applied Microbiology and Biotechnology, v.68, n.1, p.91-97. 2005. Available from: <https://doi.org/10.1007/s00253-004-1818-9>. Accessed: Jun. 23, 2019.

LÁINEZ, M. et al. Bioethanol production from enzymatic hydrolysates of Agave salmiana leaves comparing S. cerevisiae and $K$. marxianus. Renewable energy, v.138, p.1127-1133. 2019. Available from: <https://doi.org/10.1016/j.renene.2019.02.058>. Accessed: Jun. 23, 2019.

LAPPE-OLIVERAS, P. et al. Yeasts associated with the production of Mexican alcoholic non-distilled and distilled agave beverages. FEMS yeast research, v.8, n.7, p.1037-1052. 2008. Available from: $\quad<$ https://doi.org/10.1111/j.1567-1364.2008.00430.x $>$. Accessed: Jun. 23, 2019.

LEAL, J. F., ROUNTREE, M. H. Economía y sistema de haciendas en México: la hacienda pulquera en el cambio, siglos XVIII, XIX y XX. Juan Pablos editor, SA/DR Voyeur, 2011.

LEAL-DÍAZ, A. M. et al. Effect of Agave americana and Agave salmiana ripeness on saponin content from aguamiel (agave sap). Journal of agricultural and food chemistry, v. 63 , n.15, p.3924-3930. 2015. Available from: <https://doi.org/10.1021/acs. jafc.5b00883>. Accessed: Jun. 23, 2019.

LEVAC, D. Scoping studies: advancing the methodology. Implement Sci., v.5, n.69. p.9. 2010. Available from: <https:// doi.org/10.1186/1748-5908-5-69>. Accessed: Jun. 23, 2019.

LLANDERAL-CÁZARES, C. et al. Establecimiento del gusano rojo en plantas de maguey en invernadero. Acta zoológica mexicana, v.26, n.1, p.25-31. 2010. Available from: $<$ http://www.scielo.org.mx/scielo.php?script=sci_arttext\&pid $=$ S0065-17372010000100003 $>$. Accessed: Jun. 23, 2019.

LOYOLA-MONTEMAYOR, E. La industria del pulque. Departamento de Investigaciones Industriales: Banco de México SA, México, 1956

LUTZ, B. Civilizar al campesino pobre: biopolíticas alimentarias en México. RURIS-Revista do Centro de Estudos Rurais-UNICAMP, v.6, n.2. p.91-122. 2012. Available from: $<$ https://www.ifch.unicamp. br/ojs/index.php/ruris/article/view/1539>. Accessed: Jun. 23, 2019.

MACNEISH, R.S. Ancient Mesoamerica civilization. Science, v.143, n.3606, p.531-537. 1964.
MAZZETTO, E.; MORAGAS, N. Simbolismo y uso litúrgico de algunas variedades de octli entre los antiguos nahuas. Un primer acercamiento. Revista de Estudos da Religião (REVER), v.15, n.1, p.31-47. 2015. Available from: <http://revistas.pucsp.br/index. php/rever/article/view/23584>. Accessed: Jun. 23, 2019.

MIRAMONTES-CORONA, C. et al. Hydrophobic agave fructans for sustained drug delivery to the human colon. Reactive and Functional Polymers, 104396. 2019.

MONJA-MIO K. M. et al. Breeding Strategies to Improve Production of Agave (Agave spp.). In: Advances in Plant Breeding Strategies: Industrial and Food Crops. Springer, Cham. 2019. p.319-362. Available from: <https://doi.org/10.1007/978-3-03023265-8 10>. Accessed: Jun. 23, 2019.

MORA-LÓPEZ, J. L. et al. Variación morfológica y humanización de la sección Salmianae del género Agave. Agrociencia. v.45, n.4, p.465-477. 2011. Available from: <http://www.scielo.org.mx/pdf/ agro/v45n4/v45n4a6.pdf>. Accessed: Jun. 23, 2019.

MORENO-CALLES, A. I. et al. Los sistemas agroforestales tradicionales de México: una aproximación biocultural. Botanical Sciences, v.91, n.4, p.375-398. 2013. Available from: <http:// www.scielo.org.mx/pdf/bs/v91n4/v91n4a1.pdf $>$. Accessed: Jun. 23, 2019.

NARVÁEZ-SUÁREZ, A. U. et al. Maguey pulquero (Agave salmiana Otto ex Salm-Dyck): opción para desarrollo rural. AGROProductividad, v.9, n.1. 2016. Available from: <http:// revista-agroproductividad.org/index.php/agroproductividad/ article/view/832/696>. Accessed: Jun. 23, 2019.

NARVÁEZ-ZAPATA, J.; SANCHEZ-TEYER, L. Agaves as a raw material: recent technologies and applications. Recent Patents Biotechnol v.3, p.185-191. 2009. Available from: <https://www. eurekaselect.com/93546/article/agaves-raw-material-recenttechnologies-and-applications>. Accessed: Jun. 23, 2019. doi: 10.2174/187220809789389144.

NAVA-CRUZ, N. Y. et al. Agave biotechnology: an overview. Critical reviews in biotechnology, v.35, n.4, p.546-559. 2015. Available from: <https://doi.org/10.3109/07388551.2014.923813 >. Accessed: Jun. 23, 2019.

NEMSER, D. "To Avoid This Mixture": Rethinking Pulque in Colonial Mexico City. Food and Foodways, v.19, n.1-2, p.98121. 2011. Available from: <https://www.tandfonline.com/doi/ abs/10.1080/07409710.2011.544204>. Accessed: Jun. 23, 2019.

NICOLIA, A. et al. An overview of the last 10 years of genetically engineered crop safety research. Critical reviews in biotechnology, v.34, n.1, p.77-88. 2014. Available from: $<$ https://www.tandfonline.com/doi/abs/10.3109/07388551.201 3.823595? journalCode $=i b t y 20>$. Accessed: Jun. 23, 2019. doi: $10.3109 / 07388551.2013 .823595$.

PARSONS, J. R.; DARLING, J. A. Maguey (Agave spp.) utilization in Mesoamerican civilization: a case for precolumbian" Pastoralism". Boletín de la Sociedad Botánica de México, n.66, p.81-91. 2000. Available from: <https://doi.org/10.17129/ botsci.1614>. Accessed: Jun. 23, 2019.

PATEL, R. The long green revolution. The Journal of Peasant Studies, vol. 40, n.1, p.1-63. 2013. Available from: $<$ https://doi.or g/10.1080/03066150.2012.719224>. Accessed: Jun. 23, 2019. 
PERALES, L. et al. Análisis in vitro de la acumulación de metales pesados en plantas de la família Asparagaceae tolerantes a la baja disponibilidad de agua. Nova Scientia, v.24, n.12, p.1-22. 2020. Available from: <https://www.researchgate.net/ publication/340181890_Analisis_in_vitro_de_la_acumulacion_ de_metales_pesados_en_plantas_de_la_familia_Asparagaceae tolerantes_a_la_baja_disponibilidad_de_agua $>$. Accessed: Jun. 23, 2019. doi: $10.21640 /$ ns.v12i24.2081.

PUENTE-GARZA, C. A. et al. Micropropagation of Agave salmiana: Means to Production of Antioxidant and Bioactive Principles. Frontiers in Plant Science, v.6, p.1026-1026. 2015. Available from: $<$ https://doi.org/10.3389/fpls.2015.01026>. Accessed: Jun. 23, 2019.

RAMÍREZ, R. La transformación de la región pulquera en los Llanos de Apan (1910-1950). In: Campesinos y procesos rurales. Diversidad, disputas y alternativas. México, D.F.: Asociación Mexicana de Estudios Rurales, 2015. p.82-102.

REYES-AGÜERO, J. A. et al. Infraspecific variation of Agave mapisaga Trel. and A. salmiana Otto ex Salm-Dyck.

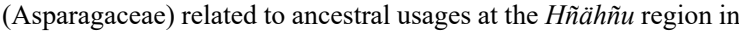
central Mexico. Agrociencia, v.53, n4, p.563-579. 2019. Available from: <http:/www.colpos.mx/agrocien/Bimestral/2019/may-jun/ art-7.pdf>. Accessed: Jun. 23, 2019.

RIVERA, G. et al. Traditional plants as source of functional foods: a review. CyTA-Journal of Food, v.8, n.2, p.159-167. 2010. Available from: <https://doi.org/10.1080/19476330903322978>. Accessed: Jun. 23, 2019.

RIVERA-VARGAS, G. A. et al. Análisis para la obtención de hidrógeno a partir de biogás proveniente de la fermentación de bebidas naturales. Ingeniería, investigación y tecnología, v.17, n.2, p.251-256. 2016. Available from: <https://doi.org/10.1016/j. riit.2016.06.009>. Accessed: Jun. 23, 2019.

ROBERTSON I. G.; CABRERA-CORTÉS M. O. Teotihuacan pottery as evidence for subsistence practices involving maguey sap. Archaeol Anthropol Sci. v.9, p.11-27. 2017. Available from: <https:// doi.org/10.1007/s12520-016-0415-z>. Accessed: Jun. 23, 2019.

RODRIGUES, H.; PARR, W. V. Contribution of cross-cultural studies to understanding wine appreciation: A review. Food Research International, v.115, p.251-258. 2019. Available from: <https://doi. org/10.1016/j.foodres.2018.09.008>. Accessed: Jun. 23, 2019.

ROJAS, G. A. et al. Diversidad genética en poblaciones de agaves pulqueros (Agave spp.) del nororiente del Estado de México. Revista Fitotecnia Mexicana, v.30, n.1, p.1-12. 2007. Available from: <https://www.revistafitotecniamexicana.org/ documentos/30-1/7r.pdf $>$. Accessed: Jun. 23, 2019.

ROJAS-RIVAS, E. et al. Consumers' perception of a traditional fermented beverage in Central Mexico. British Food Journal, v.122, n.2, p.708-721. 2019. Available from: <https://doi. org/10.1108/BFJ-05-2019-0317>. Accessed: Jun. 23, 2019.

SÁNCHEZ-MARROQUÍN, A.; HOPE, P. H. Agave juice, fermentation and chemical composition studies of some species. Journal of Agricultural and Food Chemistry, v.1, n.3, p.246249. 1953. Available from: <https://doi.org/10.1021/jf60003a007>. Accessed: Jun. 23, 2019.

SÁNCHEZ-MARROQUÍN, A. Estudio sobre la microbiología del pulque. XX Proceso industrial para la elaboración técnica de la bebida. Rev Lat-Am Microbiol Parasitol v.9, n. 9, p. 87-90. 1967.

SANTOS-ZEA, L. et al. Characterization of concentrated agave saps and storage effects on browning, antioxidant capacity, and amino acid content. Journal of Food Composition and Analysis, v.45, p.113-120. 2016. Available from: <https://doi.org/10.1016/j. jfca.2015.10.005>. Accessed: Jun. 23, 2019.

Servicio de información agroalimentaria y pesquera (SIAP). (2018). Sistema de Información Agroalimentaria de Consulta. Available from: <https:/www.gob.mx/siap/documentos/siaconng-161430>. Accessed: Jun. 23, 2019.

SILOS-ESPINO, G. et al. Chemical composition and in vitro propagation of Agave salmiana 'Gentry'. Journal of Horticultural Science and Biotechnology, v.82, n.3, p.355-359. 2007. Available from: $<$ https://doi. org/10.1080/14620316.2007.11512242>. Accessed: Jun. 23, 2019.

TONER, D. Everything in its right place? drinking places and social spaces in Mexico City, c. 1780-1900. Social History of Alcohol and Drugs, v.25, p.26-48. 2011. Available from: <https://doi. org/10.1086/SHAD25010026>. Accessed: Jun. 23, 2019.

TORRES, I. et al. Aprovechamiento, demografía y establecimiento de Agave potatorum en el Valle de Tehuacán, México: Aportes ecológicos y etnobiológicos para su manejo sustentable. Zonas Áridas, v.15, n.1, 92-109. 2016.

TORRES-GARCÍA, I. et al. The genus Agave in agroforestry systems of Mexico. Botanical Sciences, v.97, n.3, p.263-290. 2019. Available from: < https://doi.org/10.17129/botsci.2202>. Accessed: Jun. 23, 2019.

TORRES-NIETO, M. A. El pulque: Un producto turístico gastronómico sustentable. Hospitalidad ESDAI, n.24, p.55-74. 2013. Available from: <https://revistas.up.edu.mx/ESDAI/article/ view/1533>. Accessed: Jun. 23, 2019.

TOVAR-ROBLES, C. L. et al. Effect of aguamiel (agave sap) on hematic biometry in rabbits and its antioxidant activity determination. Italian Journal of Animal Science, v.10, n.2, p.21. 2011. Available from: <https://doi.org/10.4081/ijas.2011.e21>. Accessed: Jun. 23, 2019.

VALADEZ, M. J. "Pulque limpio" / "pulque sucio": disputas en torno a la legitimidad y la producción social del valor. Revista Colombiana de Antropología, v.50, n.2, p.41-63. 2014. Available from: <https://doi.org/10.22380/2539472X46>. Accessed: Jun. 23, 2019.

VALADEZ-BLANCO, R. et al. The artisanal production of pulque, a traditional beverage of the Mexican highlands. Probiotics and antimicrobial proteins, v.4, n.2, p.140-144. 2012. Available from: <https://doi.org/10.1007/s12602-012-9096-9>. Accessed: Jun. 23, 2019.

VILLARREAL-MORALES, S. L. et al. Aguamiel fresh beverage from Agave spp. Sap with functional properties. In: Natural Beverages: Volume 13: The Science of Beverages, 2019. p.179208. Available from: $<$ https://doi.org/10.1016/B978-0-12-8166895.00007-9>. Accessed: Jun. 23, 2019.

WRIGHT, A. "La Bebida Nacional": Pulque and Mexicanidad, 1920-46. Canadian journal of history, v.44, n.1, p.1-24. 2009. Available from: <https://www.utpjournals.press/doi/abs/10.3138/ cjh.44.1.197>. Accessed: Jun. 23, 2019. doi: 10.3138/cjh.44.1. 